FS IV $00-01$

Collective Wage Setting When Wages Are Generally Binding: An Antitrust

Perspective

Justus Haucap*

Uwe Pauly**

Christian Wey***

* Universität der Bundeswehr Hamburg

** Ministerium für Wirtschaft des Saarlandes

*** Wissenschaftszentrum Berlin für Sozialforschung

January 2000

ISSN Nr. 0722 - 6748

Forschungsschwerpunkt Marktprozeß und Unternehmensentwicklung

Research Area

Market Processes and Corporate Development 
Zitierweise/Citation:

Justus Haucap, Uwe Pauly, Christian Wey, Collective Wage Setting When Wages Are Generally Binding: An Antitrust Perspective, Discussion Paper FS IV 00-01, Wissenschaftszentrum Berlin, 2000.

Wissenschaftszentrum Berlin für Sozialforschung gGmbH,

Reichpietschufer 50,10785 Berlin, Tel. (030) 25491 - 0 


\title{
ABSTRACT \\ Collective Wage Setting When Wages Are Generally Binding: An Antitrust Perspective
}

\author{
by Justus Haucap, Uwe Pauly and Christian Wey ${ }^{*}$
}

This paper explores the anticompetitive effects that wage determination between an employers' association and the industry's labor union may have when wages are generally binding. It is shown that employers' associations can, under certain circumstances, use generally binding standard wages to raise rivals' costs. In equilibrium, it may be optimal for the labor union to demand a wage rate which is either above or below the entry deterring limit wage. Hence, it might be the case that a strong labor union serves as an efficiency enhancing countervailing power, because it keeps the employers' association from raising the standard wage up to the limit wage. The model is used to explain why both German employers' associations and German labor unions appear to oppose the removal of a specific legal instrument provided for in the German labor law, the so-called Allgemeinverbindlicherklärung (AVE), which makes collectively negotiated employment contracts binding for an entire industry. The entry deterring effect of the AVE suggests that labor market organization is an important determinant of product market competition and should therefore be considered as part of antitrust policies.

We would like to thank Maria Arbatskaya, Nils Gottfries, Paul Heidhues, Johan Lagerlöf, Bernhard Nagel, Rainer Nitsche, Ansgar Nolte, George von Furstenberg, and Asher Wolinsky for helpful comments and discussions. We also received valuable comments and suggestions from two anonymous referees and from participants at the meetings of the 8th Annual WZB Conference on Industrial Organization, the European Public Choice Society at Gothenburg, the European Economic Association at Berlin, the European Association of Law and Economics at Utrecht and from seminar participants at the University of Saarland and the Wissenschafts-zentrum Berlin. Of course, the usual disclaimer applies. Justus Haucap gratefully acknowledges financial support by the Deutsche Forschungsgemeinschaft (DFG) under grant Ri 15-2, and Christian Wey is most grateful for financial support by the Graduiertenförderungsstipendium of the Saarland in 1998. 


\section{Kollektive Lohnvereinbarungen und die Allgemeinverbindlicherklärung aus wettbewerbspolitischer Sicht}

Der vorliegende Aufsatz analysiert wettbewerbsbeschränkende Wirkungen, die von allgemeinverbindlichen, kollektiven Lohnabschlüssen zwischen Gewerkschaften und Arbeitgeberverbänden ausgehen können. Es wird gezeigt, daß Arbeitgeberverbände unter bestimmten Bedingungen ein Interesse an allgemeinverbindlichen Tariflöhnen haben, um strategisch die Kosten der Konkurrenz überproportional zu erhöhen (raising rivals' costs-Strategie). Durch hinreichend hohe Tariflöhne kann ein Marktzutritt von Konkurrenzunternehmen sogar vollkommen abgewehrt werden. Ob die Gewerkschaft im Gleichgewicht einen Lohn über oder unter dem marktzutrittsbeschränkenden Lohn bevorzugt, hängt von den genauen Parameterkonstellationen ab. Das Modell macht jedoch deutlich, daß eine Gewerkschaft als ,ausgleichende Kraft“ (countervailing power) in Erscheinung treten kann, die eine marktzutrittsbeschränkende Lohnsetzung durch einen monopolistischen Arbeitgeberverband vereitelt. Das Modell beleuchtet das Verhalten der deutschen Arbeitgeberverbände und Gewerkschaften und bietet eine Erklärung, warum sich beide Tarifparteien in Deutschland gegen eine Abschaffung der Allgemeinverbindlicherklärung (AVE) aussprechen, durch die kollektive Lohnabschlüsse den Charakter von Minimallöhnen annehmen. Die vorgelegte Analyse offenbart die wettbewerbsbeschränkenden Wirkungen der AVE und zeigt somit, daß die Organisation von Arbeitsmärkten entscheidenden Einfluß auf die Wettbewerbsintensität auf Gütermärkten hat. Folglich sollte die Organisation des Arbeitsmarktes auch bei der wettbewerbspolitischen Einschätzung von Gütermärkten berücksichtigt werden. 


\section{Introduction}

Labor market organization plays an important role in determining wage levels and product market structure. This paper incorporates collective wage setting institutions into an asymmetric oligopoly model and analyzes how they affect the industry's standard wage and the product market structure.

A major, if not the main, characteristic of the German labor market is its tremendously high degree of centralization. ${ }^{1}$ In Germany, unions, employers and employers' associations are granted an explicit constitutional right - the so-called Tarifautonomie - to negotiate employment contracts collectively, and most employment contracts are negotiated at the national industry level. Moreover, under Germany's labor law collective wage agreements between a union and an employers' association can be made compulsory even for independent employers in an industry through a legal instrument provided for in $§ 5$ Tarifvertragsgesetz (TVG), the so-called Allgemeinverbindlicherklärung (AVE). Even though only those unions, employers and employers' associations that have signed a collectively negotiated employment contract are directly bound by this contract ( $\S 3$ I TVG), the Ministry of Labor can, on application of either unions or employers' associations, use an AVE to make some or all employment terms generally binding for an entire industry. ${ }^{2}$ AVEs directly affect

\footnotetext{
${ }^{1}$ For a cross-national comparison of wage bargaining arrangements and institutions see BunN [1984], Calmfors \& Driffill [1988] and Layard, Nickell \& JaCkman [1991].

${ }^{2}$ There are two prerequisits of an AVE: First, at least 50 per cent of the employees in the tariff area for which an AVE is initiated have to be employed in firms of contract-bound employers ( $\$ 5$ I 1. TVG), and second, the AVE must be "in the public interest" ( $\$ 5$ I 2. TVG). However, an AVE can even be put into force if the two conditions are not met, but there exists some "social emergency" (sozialer Notstand). Hence, the Ministry of Labor has considerable discretion in applying an AVE to a certain tariff area (see LiNDENA \& HöHMANN [1988a]).
} 
about one million workers (MEYER $[1992,366]) .{ }^{3}$ Similar provisions to extend the coverage of collectively negotiated wage agreements exist in many other countries. ${ }^{4}$ The sectors mainly affected by AVEs are characterized by many small firms, low skilled workers, low capital-labor ratios, a slow expansion of domestic demand and a comparatively low degree of unionization or membership in employers' associations (Deregulierungskommission $[1991,151]$ ). As AVEs are mainly applied in low wage sectors, they effectively appear to set minimum wage standards (SACHVERSTÄNDIGENRAT [1995, 228]).

What may be surprising is that both employers' associations and unions heavily oppose any change to or removal of the legal AVE provisions although both parties claim that AVEs do not really matter much and that their impact is minor. ${ }^{5}$ The impact AVEs have on wage levels is often argued to be relatively low, as in 1998 only 588 out of 47,334 collective agreements were declared generally binding by AVEs. And only 89 of those generally binding wage agreements directly concerned wage levels (see BundeSministerium Für Arbeit und Sozialordnung [1999]). ${ }^{6}$ Furthermore, as long as most employers are members of an employers' association, there is little need to use AVEs, because member firms are directly bound through collectively negotiated wage agreements in any case.

The importance of the AVE institution might increase, however, as the organizational density of employers' associations is declining, especially - but not only - in East

\footnotetext{
${ }^{3}$ Kreimer-De Fries [1995, 212] estimates that even 1.5 to 1.7 million workers are directly affected.

${ }^{4}$ France is an especially vivid example regarding these extension rules, as in France "around half of all sectoral agreements are usually extended by government decree" (OECD [1994, 171]). In spite of a very low union density rate of 10 per cent (the lowest rate of all OECD countries) the coverage rate of collective bargaining agreements is, at a level of 90 per cent, extremely high (OECD [1994, 173]).

${ }^{5}$ For the arguments of the employers' associations see Lindena \& HöHmann [1988a], [1988b], [1989], and for the unions' side see KREIMER-DE FrIES [1995].

${ }^{6}$ It should be noted, however, that the number of AVEs almost continuously increased from 448 in 1975 to 588 in 1998.
} 
Germany (see KELler $[1997,16]$ and OECD [1994, 176]). As fewer and fewer firms are directly bound by collectively negotiated employment contracts, member firms of employers' associations bound by these agreements may be inclined to request a wider use of AVEs (SACHVERSTÄNDIGENRAT [1995, 231]). In fact, there are some indicators that the declining membership numbers of employers' associations increase the importance of AVEs. For example, in East Germany, where organizational membership is relatively low, the number of generally binding wage agreements increased from 7 in 1991 up to 163 in 1998. In addition, employers' associations in East Germany also considered using AVEs for the metal producing sector (KREIMER-DE FRIES [1995, 222ff.]).

What is even more important is that, even if the direct effects of AVEs appear to be of minor importance today, their threat-point character and indirect effects may be substantial. The threat-point character that AVEs contain has also been recognized by the German Monopolies Commission which comments that "the cartel effect of collective agreements is increased by the possibility to declare them generally binding. It is misleading to downplay the importance of this legal institution by pointing towards the small number of collective bargaining agreements declared generally binding. In January 1994, 544 out of 41,700 collective bargaining agreements have been declared generally binding. However, they aim exactly at those industries in which the eroding effects on collective bargaining agreements through outside competition would be extremely strong ... Moreover, this legal institution contains a normative threat-point potential which aims at stabilizing the system" (Monopolkommission [1994, 380]).

The idea that firms may be willing to pay higher wage rates in order to raise rivals' costs is not new. WILLIAMSON [1968] already argued that uniform wage rates may be used to force labor intensive firms to exit a particular industry. ${ }^{7}$ More specifically,

\footnotetext{
${ }^{7}$ Williamson's idea that firms are willing to bear higher costs if they can raise rivals' costs to an even larger degree has been further analyzed and refined by SALOP \& SCHEFFMAN [1983], [1987], Krattenmaker \& Salop [1986]. In line with this strand of the literature, we explain
} 
Williamson examines an industrywide wage contract, the so-called Pennington case, which raised the costs of relative labor-intensive firms to a larger extent than the costs of relative capital-intensive firms. In his analysis, Williamson uses a BainSylos-Labini type limit pricing model, in which larger firms can operate at a more efficient scale and set limit prices to prevent further market entry. Potential entrants are assumed to take the ex ante behavior of incumbent firms as given for the ex post situation when entry has occurred - an assumption that has been correctly criticized by SELTEn [1965]. Not only are oligopolistic interactions between firms neglected by WiLLIAMSON [1968], but the behavior of unions - or workers in general - is also not subject to Williamson's analysis. WILLIAMSON [1968, 91] rather assumes that "an agreement exists between the principal large scale firms in the industry and the union to impose a uniform wage on all firms in the industry independent of ability to pay." In contrast, the present paper will also analyze unions' incentives to comply with high, non-market clearing wages and introduce oligopolistic interactions into Williamson's basic analysis. ${ }^{8}$

Our analysis also overlaps with the labor market literature on the degree of wage bargaining centralization and its implications on macroeconomic outcomes (see, e.g., Calmfors \& Driffill [1988], Freeman [1988], and Jackman, Pissarides \& SAVOuri [1990]). Similar to our paper, Petrakis \& Vlassis [1997] show in this context that centralized bargaining can lead to wages above the market clearing level.

The focus of this paper is on how generally binding wage agreements affect wage determination and Cournot competition among heterogeneous firms. Particularly,

high minimum wages as a means to limit competition and to secure monopolistic rents on product markets.

${ }^{8}$ Our paper is also related to the work of Maloney, MCCormick \& Tollison [1979], who examine the role that strikes may play in restricting quantities to achieve cartel profits when the number of firms is exogeneously given, i.e., in the absence of potential entrants. In contrast to their analysis, however, we will analyze labor market institutions that raise costs, thereby preventing firms from entering the market. 
in our model we examine the strategic effects of the AVE and the incentives of the incumbent employers' association and the industry's labor union towards wage setting. The analysis gives conditions under which uniform wages might be used as an entry deterrence mechanism by the bargaining parties.

A two-stage model is analyzed under two regimes. In the first regime the incumbent employers' association has perfect monopsonistic market power on the labor market and determines the standard wage in the first stage of the game. In the second regime, we assume that the industry's labor union sets the standard wage monopolistically. In the second stage of the game the incumbent firms and the potential entrants (if they enter) compete in Cournot fashion on the product market.

We derive the subgame perfect equilibria for both regimes. When the employers' association determines the standard wage, there is an equilibrium in which it is optimal for the employers' association to set the limit wage which deters entry. If the union has all the bargaining power, we show that the labor union either chooses a wage above or below the limit wage depending on the parameters of the model. However, as in the former regime, both the labor union and the incumbent firm benefit from generally binding standard wages compared to the reference point with the competitive wage prevailing. In other words, generally binding standard wages can be used by the bargaining parties to enforce an industry cartel, which either accommodates or deters entry. The model is used to explain why both German unions and employers' associations appear to oppose the removal of the AVE, which makes collectively negotiated employment contracts binding for an entire industry. In contrast to conventional wisdom, the analysis also shows that an employers' association might prefer higher standard wages than the industry's labor union. Therefore, it might be the case that a strong labor union serves as an efficiency enhancing countervailing power, because it keeps the employers' association from raising the standard wage up to the limit wage.

The rest of the paper is organized as follows. The model is presented in Section 2. In Section 2.1 we derive the firms' equilibrium quantities in the second stage of the 
game. In Section 2.2 the optimal wage demands of the employers' association and the industry's labor union are presented and conditions are given such that the union sets a wage below the limit wage. In Section 3 we argue that wage settlements in East Germany after reunification can be explained by our model. Section 4 presents policy implications and concludes.

\section{The Model}

Consider a product market with $k$ incumbent firms and $n$ potential entrants. The $k$ incumbent firms are homogeneous and at least as efficient as the potential entrants. All incumbent firms are organized in an employers' association. There is one labor union for the industry. The model consists of a simple two-stage game. In the first stage of the game the generally binding standard wage is determined. Then, in the second stage incumbent firms and entrants (if they enter) compete in Cournot fashion on the product market. Concerning the wage setting process, we distinguish two different regimes.

1. Strong Employers' Association (EA): The employers' association has all the bargaining power on the labor market, so that it sets the generally binding standard wage in the first stage monopsonistically.

2. Strong Labor Union (U): The labor union has all the bargaining power and it determines the industry's standard wage in the first stage monopolistically.

Both regimes serve as hypothetical benchmark cases to illustrate the incentives of the bargaining parties in the presence of generally binding standard wages. Throughout our analysis we posit that the wage rate is the only variable determined in the first stage of the game. This means, we adopt the right-to-manage assumption in our 
analysis, so that each individual employer retains its own management right over its employment level. ${ }^{9}$

Let us assume that the $k$ incumbent firms and the $n$ potential entrants produce a homogeneous product. We also assume that labor is the only factor of production. The output level of each firm depends linearly on each employment level (labor input level). This means, we assume a constant-returns-to-scale technology. The incumbent firms and the potential entrants differ in their labor productivity. The labor-input-output ratio is given by $\alpha_{I}$ for the incumbent firms and by $\alpha_{E}$ for the potential entrants, respectively. ${ }^{10}$ We assume that incumbent firms are at least as efficient as entrant firms; i.e., $\alpha_{I} \leq \alpha_{E}$ holds. For a given standard wage $w$, an incumbent firm has marginal costs of $c_{I}=\alpha_{I} w$ which are (weakly) lower than the entrants' marginal costs, $c_{E}=\alpha_{E} w$. The incumbent firms are indexed by $i=(1, \ldots, k)$ and the potential entrants by $j=(k+1, \ldots, N)$, with $N-k=n$.

In the following, quantities are denoted by $q$, prices by $p$ and aggregate output by $Q$. The aggregate output, $Q$, is the sum over all quantities produced by the incumbent firms, $Q_{I} \equiv \sum_{i=1}^{k} q_{i}$, and the aggregate output of the potential entrants, $Q_{E} \equiv \sum_{j=k+1}^{N} q_{j}$; i.e., $Q=Q_{I}+Q_{E}$. The inverse demand schedule is assumed to be linear and given by $p=a-b Q$ for positive quantities.

The utility function of the industry's labor union is given by $W=(w-\hat{w}) l$, where $\hat{w}$ stands for the reservation wage of the employees, and $l$ denotes the employment level in the industry. ${ }^{11}$ This means, the union maximizes its wage revenues, which

\footnotetext{
${ }^{9}$ In contrast to the right-to-manage model (see for example NiCKell \& ANDREws [1983]), the efficient-bargaining model stipulates that the unions and the firms bargain over wages and firms' employment levels. For discussions of both approaches see LAYARD, NiCKELl \& JACKMAN [1991] and Bughin [1999].

${ }^{10}$ The subscript "I" stands for an incumbent firm and the subscript "E" stands for a potential entrant.

${ }^{11}$ The wage bill utility function, which is a specific form of a more general quasi-concave union utility function, is often used in the literature (see McDonald \& Solow [1981] and Oswald [1985]). For other specifications of the union's utility function see OswaLD [1985].
} 
are the surplus income on top of the wage bill under perfect competition in the labor market. ${ }^{12}$ We assume that all workers in the industry are members of the labor union, so that $l=Q_{I} \alpha_{I}+Q_{E} \alpha_{E}$ holds. The workers' reservation wage, $\hat{w}$, which is the market clearing wage, is assumed to be exogenous and normalized to zero. $^{13}$

\subsection{Cournot Oligopoly Equilibrium}

By backward induction, we now solve for the equilibrium in the second stage of the game taking the industry's standard wage, $w$, as given. The profit functions of the incumbent firms and the potential entrants are given by $\Pi_{I}=\left(a-b Q-\alpha_{I} w\right) q_{I}$ and $\Pi_{E}=\left(a-b Q-\alpha_{E} w\right) q_{E}$, respectively. The Cournot-Nash equilibrium output pair of the second stage of the game $\left(q_{I}, q_{E}\right)$ is determined by solving the $k+n$ best response functions for each firm:

$$
q_{t}\left(Q_{-t}\right)=\frac{1}{2 b}\left(a-b \sum_{i=1, i \neq t}^{k} q_{i}-b Q_{E}-\alpha_{I} w\right), \text { for } t=1, \ldots, k,
$$

and

$$
q_{t}\left(Q_{-t}\right)=\frac{1}{2 b}\left(a-b Q_{I}-b \sum_{j=k+1, j \neq t}^{N} q_{j}-\alpha_{E} w\right), \text { for } t=k+1, \ldots, N
$$

where $Q_{-t}$ is the aggregate output of firm t's competitors. By solving (1) and (2) for $q_{t}$ we derive the unique (and type-symmetric) Cournot-Nash equilibrium which is given $b^{14}$

$$
q_{I}=\frac{a+w\left(n \alpha_{E}-(n+1) \alpha_{I}\right)}{b(N+1)},
$$

\footnotetext{
${ }^{12}$ In the case of Germany, this assumption reflects the fact that unions receive about 1 per cent of their members' payroll.

${ }^{13}$ Under the Nash Bargaining solution the term $\hat{w}$ is the union's threat point. It is common practice in the literature to normalize the workers' reservation wage $\hat{w}$ to zero (see, e.g., BugHIN $[1999,1032])$.

${ }^{14}$ Second-order conditions require $-b(k+1)<0(-b(n+1)<0)$ for the incumbent (entrant) firms.
} 


$$
q_{E}=\frac{a-w\left((k+1) \alpha_{E}-k \alpha_{I}\right)}{b(N+1)}
$$

and the aggregate industry output is

$$
Q=k q_{I}+n q_{E}=\frac{N a-w\left(n \alpha_{E}+k \alpha_{I}\right)}{b(N+1)}
$$

If the potential entrants do not enter the market, equation (3) reduces to

$$
\tilde{q}_{I}=\frac{a-\alpha_{I} w}{b(k+1)}
$$

where the tilde indicates that only the $k$ incumbent firms are active. Calculating the reduced profit functions shows that the equilibrium profit for firm $t$ is equal to $b q_{t}^{2}$, and therefore depends only on firm t's quantity.

We can now examine how an increase of the standard wage affects the firms' equilibrium outputs. Taking the derivative of equation (4) with respect to the standard wage $w$ gives

$$
\frac{\partial q_{E}}{\partial w}=-\frac{(1+k) \alpha_{E}-k \alpha_{I}}{b(N+1)}<0
$$

The equilibrium output of the entrant firms is strictly decreasing for increasing levels of the standard wage. An entrant firm's decision to produce a positive amount depends on whether or not it can obtain a positive profit. From equation (4) we can calculate the limit wage, $w_{0}$, such that for all $w \geq w_{0}$ an entrant firm produces nothing. The result is stated in Lemma 1.

Lemma 1 The entrant firms do not produce if and only if $w \geq w_{0}$, with $w_{0}=$ $\frac{a}{\alpha_{E}+k\left(\alpha_{E}-\alpha_{I}\right)}$.

Proof. By definition of $w_{0}, q_{E}\left(w_{0}\right)=0$. Thus, $\frac{a-w\left((1+k) \alpha_{E}-k \alpha_{I}\right)}{b(N+1)}=0$, and hence $w_{0}=\frac{a}{\alpha_{E}+k\left(\alpha_{E}-\alpha_{I}\right)}$. Q.E.D.

For the incumbent firms we obtain

$$
\frac{\partial q_{I}}{\partial w}=\frac{n \alpha_{E}-(n+1) \alpha_{I}}{b(N+1)},
$$


which is non-negative if and only if

$$
\frac{\alpha_{E}}{\alpha_{I}} \geq \frac{n+1}{n}
$$

As long as the entrant firms are active, the equilibrium output of the incumbent firms strictly decreases with increasing standard wages if $\frac{\alpha_{E}}{\alpha_{I}}<\frac{n+1}{n}$. If, however, $\frac{\alpha_{E}}{\alpha_{I}} \geq$ $\frac{n+1}{n}$ holds, the incumbent firms' output level (weakly) increases with an increasing standard wage. Lemma 2 characterizes the incumbent firms' output (profit) level depending on the industry's standard wage.

Lemma 2 The incumbent firm's output (profit) reaches a global maximum at $w=$ $w_{0}$ if $\frac{\alpha_{E}}{\alpha_{I}} \geq \frac{n+1}{n}$ holds. For $\frac{\alpha_{E}}{\alpha_{I}}<\frac{n+1}{n}$ the incumbent firm's output (profit) is maximized at $w=0$.

Proof. We prove the first part of the lemma. From equation (8) we know that $q_{I}$ is (weakly) increasing over the interval $w \in\left[0, w_{0}\right)$ if and only if $\frac{\alpha_{E}}{\alpha_{I}} \geq \frac{n+1}{n}$. For $w \in\left[w_{0},\left(a / \alpha_{I}\right)\right)$ Lemma 1 and equation (6) imply that only the incumbent firms are active and that the incumbent firms' output, $\tilde{q}_{I}$, is strictly decreasing in $w$. Therefore, $q_{I}$ reaches a global maximum at $w_{0}$ with $q_{I}\left(w_{0}\right)=\frac{a\left(\alpha_{E}-\alpha_{I}\right)}{b\left(\alpha_{E}+k\left(\alpha_{E}-\alpha_{I}\right)\right.}$. The second part follows directly from inspection of equation (3). Q.E.D.

Lemma 2 states that the incumbent firms' profits are maximized at the limit wage, if condition (9) holds. As long as condition (9) is fulfilled, the more efficient incumbent firms benefit from an industrywide wage increase up to the point where the less efficient entrant firms cease to produce and do not enter the market. Because $\frac{\alpha_{E}}{\alpha_{I}} \geq 1$ holds by assumption, condition (9) is the more likely to hold the larger the number of potential entrants is. Let us also point out that total industry output is strictly decreasing as $w$ increases, so that the level of total industry employment is maximized at $w=0$.

Figure 1 depicts the equilibrium quantities for the incumbent and the entrant firms in the case in which condition (9) is strictly fulfilled. An incumbent firm's market share is strictly greater than the market share of the entrant firm, whenever the 
Figure 1: Equilibrium Quantities and Incumbent Firms' Profits $\left(\frac{\alpha_{E}}{\alpha_{I}}>\frac{n+1}{n}\right)$

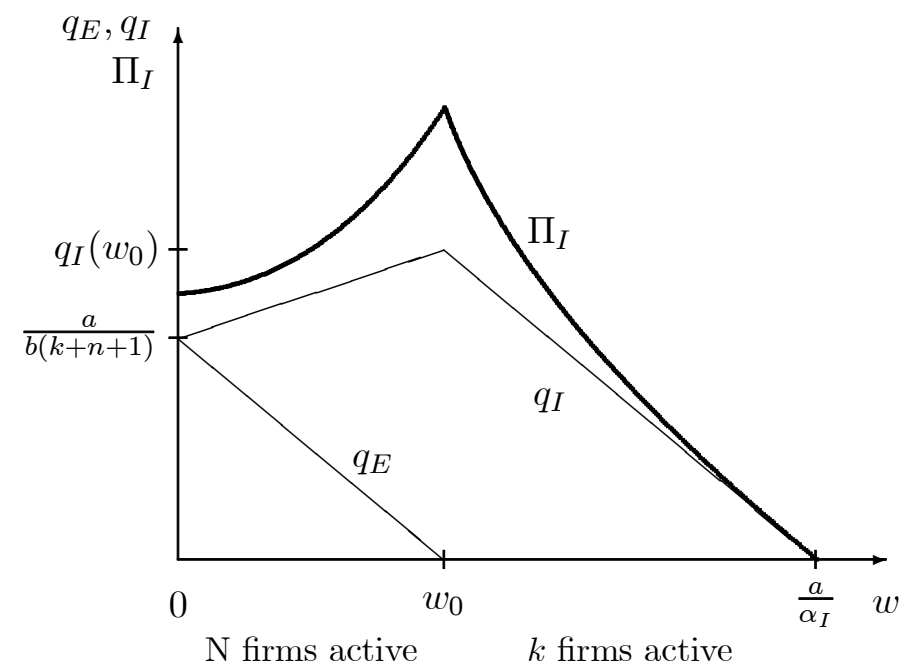

standard wage rate is positive. Incumbent firms' profits are maximized at the limit wage $w_{0}$. The bold curve in Figure 1 represents the incumbent firm's equilibrium profits, $\Pi_{I}$, which are a strictly convex function in $w{ }^{15}$

\section{$2.2 \quad$ Wage Setting}

We now derive the optimal wage demand of the employers' association and the labor union, taking the optimal strategies in the second stage of the game as given. First, we examine Regime EA in which the employers' association has all the bargaining power, so that it determines the standard wage as a monopsonist. Thereafter, we analyze Regime $\mathrm{U}$ where we assume that the labor union has all the bargaining power.

\footnotetext{
${ }^{15}$ The strict convexity of $\Pi_{I}$ can be easily checked by substituting the equilibrium quantities into the incumbent firm's profit function $\Pi_{I}=b q_{I}^{2}$, and differentiating with respect to $w$ twice. For wages below $w_{0}$, we obtain $\frac{d^{2} \Pi_{I}}{d w^{2}}=\frac{2}{b}\left(\frac{n \alpha_{E}-\alpha_{I}(n+1)}{N+1}\right)^{2}>0$, and for wages $w \in\left[w_{0}, \frac{a}{\alpha_{I}}\right)$, we get $\frac{d^{2} \Pi_{I}}{d w^{2}}=\frac{2}{b}\left(\frac{\alpha_{I}}{k+1}\right)^{2}>0$.
} 


\subsubsection{Strong Employers' Association (EA)}

Only the incumbent firms are organized, so that all members of the employers' association are identical. The optimal strategy for the employers' association at the first stage of the game, $w^{E A}$ (the superscript "EA" indicates Regime EA), is defined as

$$
w^{E A}=\arg \max _{w} \sum_{i=1}^{k} \Pi_{i}\left(q_{I}(w), q_{E}(w)\right),
$$

subject to the constraint that $w^{E A}$ has to be at least as large as the workers' reservation wage, $\hat{w}$, which we normalize to zero. As mentioned above, $\hat{w}$ is the reference equilibrium wage rate that would be realized on a perfectly competitive market, in absence of any labor market institution such as employers' associations or unions. The solution to this maximization problem is stated in Proposition 1.

Proposition 1 The employers' association maximizes its members' profits by setting the standard $w^{E A}$ equal to the limit wage $w_{0}$, whenever $\frac{\alpha_{E}}{\alpha_{I}} \geq \frac{n+1}{n}$ holds. Otherwise, the employers' association chooses $w^{E A}=\hat{w}=0$.

Proof. Follows directly from Lemma 2 and the fact that the objective function of the employers' association is the sum of its identical members' profits. Q.E.D.

From Lemma 2 we know that the incumbent firms' profits are maximized at $w_{0}$ if and only if condition (9) holds. Therefore, all incumbent firms would like to raise rivals' costs by increasing the standard wage to the limit wage, $w_{0}$. This leads to decreasing total industry output, and hence, to a reduction in labor input and employment levels. If, however, incumbent and entrant firms have almost the same labor productivity (i.e. $\frac{\alpha_{E}}{\alpha_{I}}<\frac{n+1}{n}$ ), the employers' association maximizes its members' profits by setting the industry's standard wage equal to the workers' reservation wage, with $w^{E A}=\hat{w}=0$. 


\subsubsection{Strong Labor Union (U)}

Now we turn to the optimal wage demand of the labor union. The optimal wage setting strategy of the labor union, $w^{U}$ (the superscript "U" stands for Regime U), at the first stage of the game is defined as

$$
w^{U}=\arg \max _{w} W\left(q_{I}(w), q_{E}(w)\right)
$$

subject to $w^{U} \geq \hat{w}=0$. The union's wage revenues, $W\left(q_{I}(w), q_{E}(w)\right)$, are given by

$$
W \equiv \begin{cases}W_{N}=\left[\alpha_{I} Q_{I}(w)+\alpha_{E} Q_{E}(w)\right] w: 0 \leq w<w_{0} \\ W_{k}=\left[\alpha_{I} Q_{I}(w)\right] w & : w_{0} \leq w<\frac{a}{\alpha_{I}} \\ 0 & : \frac{a}{\alpha_{I}} \leq w .\end{cases}
$$

The union's revenue function (12) consists of three parts. For wage levels $w \in\left[0, w_{0}\right)$ all firms are active, so that both the incumbent and the entrant firms contribute to industry wage revenues. For wages above the limit wage, $w_{0}$, only the efficient incumbent firms remain active on the product market, and wage revenues are given by $W_{k}$. Of course, for wages above $\frac{a}{\alpha_{I}}$ even the incumbent firms cease to produce, so that wage revenues are zero in this case.

In order to derive the optimal wage offer of the labor union, we now derive some properties of the wage revenue schedule. Both wage revenue functions $W_{N}$ and $W_{k}$ are strictly concave with respect to $w$. Hence, there are in principle two candidate values of $w$ at which the union's overall wage revenue function is maximized. Wage revenues might reach their absolute maximum at a wage below the limit wage, $w_{0}$, or at a wage above the limit wage. In the former case the union prefers all $N=k+n$ firms being active on the product market. In the latter case, the union maximizes overall wage revenue when only the incumbent firms produce and the entrant firms do not enter the market. 
Substituting the equilibrium quantities $q_{I}, q_{E}$, and $\tilde{q}_{I}$ from equations (3), (4), and (6), respectively, into (12), we obtain

$$
W \equiv \begin{cases}W_{N}=\frac{w\left[a\left(k \alpha_{I}+n \alpha_{E}\right)-w\left(n \alpha_{E}^{2}+n k\left(\alpha_{E}-\alpha_{I}\right)^{2}+k \alpha_{I}^{2}\right)\right]}{b(N+1)} & : 0 \leq w<w_{0} \\ W_{k}=\frac{w k \alpha_{I}\left(a-w \alpha_{I}\right)}{b(k+1)} & : w_{0} \leq w<\frac{a}{\alpha_{I}} \\ 0 & : \frac{a}{\alpha_{I}} \leq w\end{cases}
$$

Differentiation of $W_{N}$ with respect to $w$ yields the revenue maximizing wage level (where the subscript "N" indicates that all $k+n$ firms are active): ${ }^{16}$

$$
w_{N}=\frac{a\left(k \alpha_{I}+n \alpha_{E}\right)}{2\left(n \alpha_{E}^{2}+n k\left(\alpha_{E}-\alpha_{I}\right)^{2}+k \alpha_{I}^{2}\right)} .
$$

Similarly, we obtain the revenue maximizing wage level for $W_{k}$ (where the subscript " $\mathrm{k}$ " indicates that only the $k$ incumbent firms are active):

$$
w_{k}=\frac{a}{2 \alpha_{I}}
$$

Straight forward comparison of equations (14) and (15) yields that $w_{N}<w_{k}$ holds for all parameters $\alpha_{E}, \alpha_{I}, k, n>0$, with $\alpha_{E} \geq \alpha_{I}$. Lemma 3 gives a necessary and sufficient condition such that $w_{N} \leq w_{0}$ holds.

Lemma 3 The inequality $w_{N} \leq w_{0}$ is satisfied for all parameter vectors $\left(\alpha_{E}, \alpha_{I}, k, n\right) \in$ $R_{+}^{2} \times N_{+}^{2}$, with $\alpha_{E} \geq \alpha_{I}$, if and only if

$$
\frac{\alpha_{E}^{2}}{\alpha_{I}^{2}} n(k+1)-\frac{\alpha_{E}}{\alpha_{I}} k(3 n+k+1)+k(2 n+k+2) \geq 0 .
$$

Proof. We have to specify the range of parameters for which $w_{N} \leq w_{0}$ holds. Comparison of $w_{N}$ and $w_{0}$ yields

$$
w_{N} \leq w_{0} \Leftrightarrow \frac{a\left[k \alpha_{I}^{2}\left(k+2(n+1)+n \alpha_{E}^{2}(k+1)-k \alpha_{E} \alpha_{I}(3 n+k+1)\right]\right.}{2\left(\alpha_{E}+k\left(\alpha_{E}-\alpha_{I}\right)\right)\left[k n\left(\alpha_{E}-\alpha_{I}\right)^{2}+k \alpha_{I}^{2}+n \alpha_{E}^{2}\right]} \geq 0 .
$$

Since the denominator of the inequality's left-hand side is strictly positive, rewriting gives condition (16). Q.E.D.

\footnotetext{
${ }^{16}$ The second-order condition is satisfied: $-\left(n \alpha_{E}^{2}+n k\left(\alpha_{E}-\alpha_{I}\right)^{2}+k \alpha_{I}^{2}\right)<0$.
} 
Table 1: Values of $\bar{n}$

\begin{tabular}{|l||l|l|l|l|l|l|l|l|}
\hline$k$ & 1 & 2 & 3 & 4 & 5 & 6 & 7 & $k \geq 8$ \\
\hline $\bar{n}$ & $\emptyset$ & $\emptyset$ & 2 & 5 & 10 & 21 & 56 & $\infty$ \\
\hline
\end{tabular}

The left-hand side of inequality (16) is a U-shaped function in $\frac{\alpha_{E}}{\alpha_{I}}$ which has two potential roots along the real axis. If no real root exists, $w_{N}<w_{0}$ holds for all parameter vectors under consideration. Inspection of condition (16) reveals that this condition is the more likely to be fulfilled, the closer $\frac{\alpha_{E}}{\alpha_{I}}$ is to one. Indeed, (16) is fulfilled for all parameters $\alpha_{E}, \alpha_{I}, k, n>0$, whenever the productivity difference between the incumbent and the entrant firms vanishes. Calculating the roots of the left-hand side of condition (16) with respect to $\frac{\alpha_{E}}{\alpha_{I}}$, one obtains two solutions

$$
\begin{aligned}
& \left(\frac{\alpha_{E}}{\alpha_{I}}\right)_{1} \leq \frac{k(3 n+k+1)-\sqrt{\rho}}{2 n(k+1)} \equiv \underline{\mu}, \\
& \left(\frac{\alpha_{E}}{\alpha_{I}}\right)_{2} \geq \frac{k(3 n+k+1)+\sqrt{\rho}}{2 n(k+1)} \equiv \bar{\mu},
\end{aligned}
$$

where $\rho \equiv n^{2} k(k-8)+2 n k\left(k^{2}-3 k-4\right)+k^{2}\left(k^{2}+2 k+1\right)$. For those solutions being real $\rho$ has to be non-negative. Obviously, $\rho$ can only be negative if $k<8$. Table 1 gives the maximum number of entrant firms, $\bar{n}$, for all values of $k$, such that $\rho$ is non-negative. From Table 1 we observe that, e.g., for $k=3$ the maximum number of entrant firms is 2 , in order to get a real solution. Hence, for $k=3$ and $n=2$ there exists a parameter vector such that the wage revenue function is increasing for all $w \in\left[0, w_{0}\right)$. The wage revenue function, $W_{N}$, always reaches its maximum at a wage below $w_{0}$, if no real solution to inequality (16) exists, since in this case the condition is always satisfied. As can be seen from Table 1, this situation occurs for $k \leq 7$ if $n>\bar{n}$. If there are only one or two incumbent firms, then condition (16) holds for all considered parameter vectors.

In the case where only the $k$ incumbent firms are active the following condition assures that the maximum of the wage revenue function $W_{k}$ is reached at a wage 
$w=w_{k}$, which is strictly greater than the limit wage, $w_{0}$ :

$$
w_{k}>w_{0} \Leftrightarrow \frac{\alpha_{E}}{\alpha_{I}}>\frac{k+2}{k+1} .
$$

If condition (17) is not met, the wage revenue function $W_{k}$ is strictly decreasing over the interval $w \in\left[w_{0}, \frac{a}{\alpha_{I}}\right)$, where only the $k$ incumbent firms remain in the market. Assume now that condition (16) is satisfied. Then, a sufficient condition that the union's objective function reaches its global maximum at $w_{N}$ is given by $W_{N}\left(w_{N}\right)>W_{k}\left(w_{k}\right)$, what is equivalent with

$$
\frac{\alpha_{E}}{\alpha_{I}}<\frac{N+2}{N+1-\frac{n}{k}} .
$$

As can be easily verified the right-hand side of inequality (18) is strictly greater than one. Based on these intermediate results concerning the wage revenue function, we can now state the optimal wage setting of the labor union in Proposition 2.

Proposition 2 The standard wage, $w^{U}$, which maximizes the labor union's objective function, is given by the following two values:

(i) $w^{U}=w_{N}$, if $1 \leq \frac{\alpha_{E}}{\alpha_{I}}<\min \left\{\underline{\mu}, \frac{N+2}{N+1-\frac{n}{k}}\right\}$, or $\bar{\mu}<\frac{\alpha_{E}}{\alpha_{I}}<\frac{N+2}{N+1-\frac{n}{k}}$ holds, and (ii) $w^{U}=w_{k}$, if $\underline{\mu} \leq \frac{\alpha_{E}}{\alpha_{I}} \leq \bar{\mu}$, or $\frac{\alpha_{E}}{\alpha_{I}} \geq \frac{N+2}{N+1-\frac{n}{k}}$ is satisfied.

Proof. Assume $\underline{\mu} \leq \frac{\alpha_{E}}{\alpha_{I}} \leq \bar{\mu}$ holds. Hence, $W_{N}$ is strictly increasing over the interval $w \in\left[0, w_{0}\right)$. Since $\underline{\mu}>\frac{k+2}{k+1}$, we know that $W_{k}$ is strictly increasing at the point $w_{0}$, at which $W_{N}=W_{k}$ holds. Hence, $W_{k}\left(w_{k}\right)$ is greater than $W_{N}(w)$, for all $w<w_{0}$ if $\frac{\alpha_{E}}{\alpha_{I}} \in[\underline{\mu}, \bar{\mu}]$. Inequality (18) is a sufficient condition for $w_{N}$ being the global maximum. Therefore, we know that the global maximum is reached at $w_{N}$ if condition (18) holds and $\frac{\alpha_{E}}{\alpha_{I}} \notin[\underline{\mu}, \bar{\mu}]$. This proves (i) and the first part of (ii). For the second part of (ii), we have $W_{k}\left(w_{k}\right) \geq W_{N}\left(w_{N}\right)$, for all $\frac{\alpha_{E}}{\alpha_{I}} \geq \frac{N+2}{N+1-\frac{n}{k}}$, since $\frac{k+2}{k+1}<\frac{N+2}{N+1-\frac{n}{k}}$ holds, for all $k, n>0$. Q.E.D.

The following Proposition 3 specifies the intervals such that the employers' association (union) demands a higher standard wage than the labor union (employers' association). 
Proposition 3 Comparison of the optimal wage setting strategies of the employers association, $w^{E A}$, and the labor union, $w^{U}$, yields:

(i) $w^{E A}>w^{U}$ : The employers' association wants to set a higher standard wage than the labor union, if $\frac{n+1}{n} \leq \frac{\alpha_{E}}{\alpha_{I}}<\min \left\{\underline{\mu}, \frac{N+2}{N+1-\frac{n}{k}}\right\}$, or $\bar{\mu}<\frac{n+1}{n} \leq \frac{\alpha_{E}}{\alpha_{I}}<\frac{N+2}{N+1-\frac{n}{k}}$ holds.

(ii) $w^{U} \geq w^{E A}$ : The labor union wants to set a (weakly) higher standard wage than the employers' association, if $1 \leq \frac{\alpha_{E}}{\alpha_{I}}<\frac{n+1}{n}$, or $\underline{\mu} \leq \frac{n+1}{n} \leq \frac{\alpha_{E}}{\alpha_{I}} \leq \bar{\mu}$, or $\frac{N+2}{N+1-\frac{n}{k}} \leq \frac{n+1}{n} \leq \frac{\alpha_{E}}{\alpha_{I}}$ holds.

Proof. From Proposition 1 it follows that the employers' association prefers the limit wage, $w_{0}$, if $\frac{\alpha_{E}}{\alpha_{I}} \geq \frac{n+1}{n}$ is satisfied. From Proposition 2 it follows that the labor union prefers $w_{N}$, if $1 \leq \frac{\alpha_{E}}{\alpha_{I}}<\min \left\{\underline{\mu}, \frac{N+2}{N+1-\frac{n}{k}}\right\}$, or $\bar{\mu}<\frac{\alpha_{E}}{\alpha_{I}}<\frac{N+2}{N+1-\frac{n}{k}}$ holds. Since $w_{N}<w_{0}$ holds, part (i) of Proposition 3 follows. Part (ii) follows from $w_{N}, w_{k}>\hat{w}=0$ and $w_{0} \leq w_{k}$. Q.E.D.

According to Proposition 3, a strong employers' association may prefer a higher standard wage than a strong union. Of course, the optimal wage demand of the employers' association is strictly below the union's optimal wage, whenever the productivity lead of the incumbent firms is small, such that $\frac{\alpha_{E}}{\alpha_{I}}<\frac{n+1}{n}$ holds. The employers' association, however, will set the limit wage, if the labor productivity difference between incumbent and entrant firms is relatively large; i.e., $\frac{\alpha_{E}}{\alpha_{I}} \geq \frac{n+1}{n}$. If conditions (16) and (18) are fulfilled for some $\frac{\alpha_{E}}{\alpha_{I}}>\frac{n+1}{n}$, then there exists a vector of parameters $\left(\alpha_{E}, \alpha_{I}, k, n\right) \in R_{+}^{2} \times N_{+}^{2}$, such that the labor union prefers a lower wage than the employers' association. In this case, the labor union benefits from accommodating entry, and wants to set a wage strictly below the limit wage. Hence, in contrast to conventional wisdom, it might be the case that the existence of a strong union is efficiency enhancing. Given that wage agreements are generally binding, a strong union might act as a countervailing power, which prevents the employers' association from setting the entry deterring wage.

As Proposition 3 shows, it is also possible that the union prefers a wage strictly higher than the limit wage. If the union had all the bargaining power, it would push 
the standard wage to even higher levels than the employers' association would do. While many people appear to believe that this is always the case, our analysis has identified conditions under which the contrary is true.

Figure 2 compares the optimal wage strategy of the employers' association and the union for different values of $\alpha_{E}$, holding everything else constant. It is also assumed that the number of potential entrants is strictly larger than the number of incumbent firms ${ }^{17}$ and that the intersection between the $w_{N}$-curve and the $w_{0}$-curve is to the

right of $\frac{N+2}{N+1-\frac{n}{k}}$. Figure 2 illustrates that the labor union's incentives to deter entry are on average lower compared with those of the employers' association. Entry deterrence is optimal from the union's perspective, whenever the productivity lead of the incumbent firms is relatively large. As a result, there is a range of parameters for which the employers' association wants to deter entry, while the union prefers the wage, $w_{N}$, at which entry is accommodated.

Finally, let us point out that both the employers' association and the labor union benefit from collective wage settlements which are generally binding for the entire industry compared with the competitive equilibrium, where $\hat{w}=0$ prevails.

\section{The Deep-Freeze of the East German Economy}

The cartelization effect of bilateral wage agreements and their potentially devastating effects for employment levels are illustrated by the East German experience after the German reunification in 1990. In general, East Germany's prospects for economic prosperity were believed to be rather shiny, mainly because of its welleducated and skilled labor force and its rich brother state, which was expected to generously help with capital as well as technological and organizational know-how. However, as has been painfully experienced in the last decade, "one of the worst and sharpest depressions in European history had begun" with the economic union

${ }^{17}$ This condition follows from $\frac{n+1}{n} \leq \frac{k+2}{k+1}$. 
Figure 2: Comparison of Optimal Wages $\left(\alpha_{I}=1, n>k, \underline{\mu}>\frac{N+2}{N+1-\frac{n}{k}}\right)$

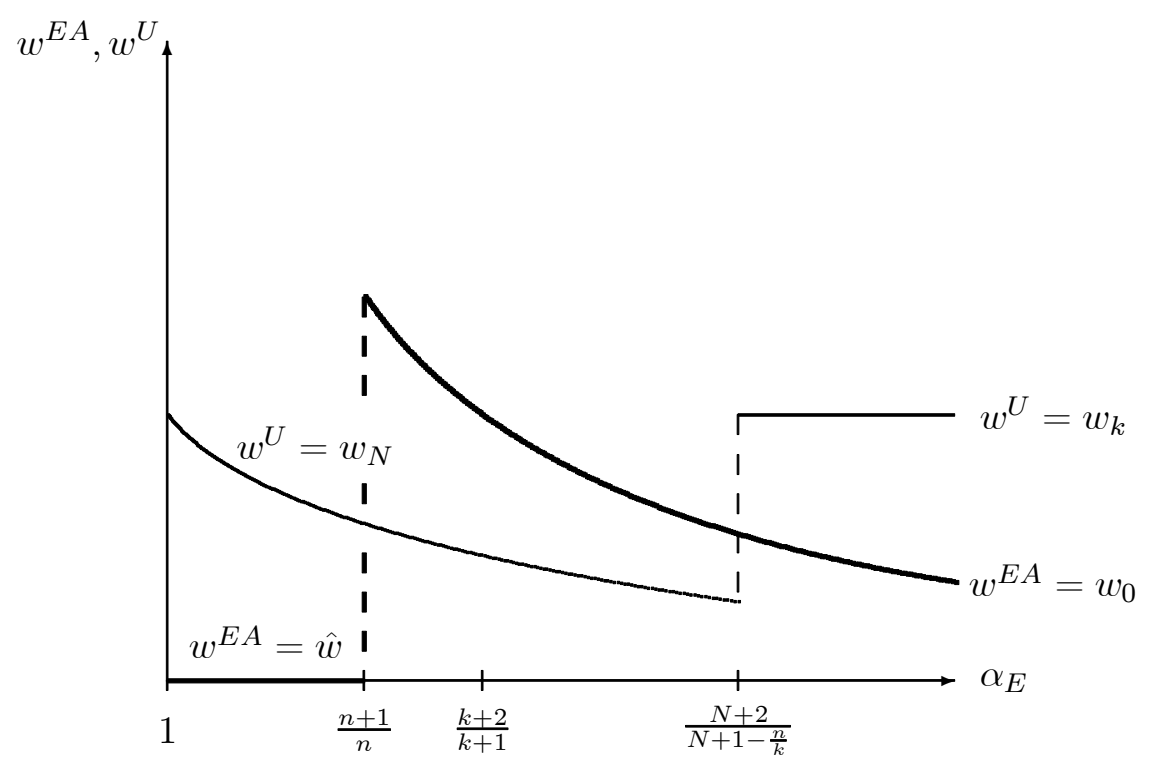

(Akerlof, Rose, Yellen \& Hessenius $[1991,1]$ ). The effects on unemployment have been devastating. ${ }^{18}$

Akerlof, Rose, Yellen \& Hessenius [1991] mainly blame unions for recklessly pushing wage parity between East and West Germany, and their analysis "clearly singles out West German unions as the villains in the collapse" (DoRNBUsch [1991, 89]). While there is certainly some merit in this argument, it is our view that employers' associations are not as innocent as their analysis implicitly suggests. After the German reunification the West German collective bargaining system was immediately adopted for East Germany. West German employers' associations joined the collective bargaining table, ${ }^{19}$ and as SINN \& SinN [1992, 165 ff.] have convincin-

\footnotetext{
${ }^{18}$ Employment in the manufacturing sector had declined by 74 per cent by the end of 1993 (Deutsche Bundesbank, June 1994, 84). From Fall 1989 to 1992, one in three workers lost their jobs, in total some three million people. The industrial sector saw the largest lay-offs, as more then 1.7 million jobs were lost. For a discussion of the German labor market situation after the reunification see FrAnz [1991], Scheremet [1992], and SchEREMET \& Schupp [1992].

${ }^{19}$ Unions were already well established in East Germany before 1990, and membership numbers in East Germany were comparatively high. Furthermore, the largest employer was the Treuhand,
} 
gly argued, West German employers did not have any interest in low wages in the East. Low wage levels in the East would have made the less efficient East German firms competitive and thereby devalued the employers' existing capital in the West. Unsurprisingly, wages settled on a high level and increased tremendously. ${ }^{20}$

Even though investment in East Germany became less attractive as a result of the high wage levels, the strategy helped protecting profits in the West. Why did the East German unions not resist the wage increases? One reason might be that they were "assisted" by West German union representatives because the East German unionists were allegedly too unexperienced in matters concerning collective bargaining. Like the West German employers, however, West German unions were not too interested in low wage competition from the East either. In accordance with our model, a collective bargaining agreement was reached in March 1991 which aimed at an equalization of wages in East and West by 1994 and which significantly raised barriers to entry for the less efficient firms from the East. Both bargaining parties were quite successful in securing their members' interests by raising wages and avoiding outside competition. The contrary nature of unions and employers' associations was set aside in order to stabilize the wage setting cartel.

a state agency, supervising all state-owned enterprises. The labor-managers of the firms under Treuhand supervision were in a conflicting situation. On the one hand, they were employers at the bargaining table. On the other hand, they were simply employees of the Treuhand in the end. Therefore, it was not surprising that these "employers" did not show strong resistance to wage increases which devalued the existing capital (not owned by themselves).

${ }^{20}$ Although the productivity in East Germany is well below the West German level, workers in the East were paid about 69 per cent of their western colleagues' wage per hour in 1996 (INSTITUT Der Deutschen Wirtschaft [1997, chart 137]). The resulting increase of unit labor costs seems to be the major factor for the excessive employment problems in East Germany. DoRNBUSCH [1992] already identified this problem shortly after the reunification. 


\section{Policy Implications and Conclusions}

In this paper we developed a simple model to analyze the effects of extension rules - as, e.g., the AVE in Germany - on wage setting and product market competition. Our analysis has shown that collective agreements about generally binding standard wages can induce industry concentration on the product market accompanied with falling sectorial employment levels because both the union and the employers' association may have incentives to increase the standard wage above the market clearing level. It has been shown that this cartelization effect of collective wage agreements which are generally binding is largely independent of the distribution of the bargaining power between the two parties. This result stands in some contrast to more traditional reasoning which emphasizes the efficiency aspects of employers' associations in the bargaining process. As, for example, NiCKELL [1997, 68] argues, "unions are bad for jobs, but these bad effects can be nullified if both the unions and the employers can coordinate their wage bargaining activities." According to our model the opposite might also happen. Employers' associations which are dominated by incumbent firms may even worsen wage bargaining outcomes in terms of product market competition and sectorial employment levels. Our paper therefore demonstrates that unions may improve the wage bargaining outcome. A strong labor union may serve as an efficiency enhancing countervailing power, because it keeps the employers' association from raising the standard wage up to the limit wage.

The adverse effects of centralized wage bargaining for the level of unemployment call for an extension of antitrust measures to the labor market. The use of instruments designed to make wage settlements generally binding for entire industries should be deemed to be anticompetitive, and the use of such instruments should induce investigations by antitrust authorities.

In general, the entry deterrence effect of the AVE suggests that labor market organization is an important determinant of product market competition and should 
therefore be considered in antitrust policies. It is often argued that collective wage agreements together with extension rules are efficiency enhancing, because of transaction and bargaining cost reasons. Those savings may well outweigh the additional enforcement costs and the welfare loss associated with reduced competition. However, in this case it may be more appropriate from a public policy point of view to impose a requirement on the bargaining parties to get an authorization for the respective agreement from antitrust or competition agencies. That would mean the bargaining parties have to demonstrate the efficiency gains associated with their agreement.

Let us also clarify that our model examines the implications of generally binding wage agreements for a closed economy. Given that barriers to international trade are now relatively low between Germany and many other jurisdictions, we would expect the AVE to be of lesser importance for tradable than for non-tradable goods. Especially in service industries the AVE may still play a significant role, as service industries are often labor-intensive and the services produced are often not tradable.

In summary, it is our view that legal instruments that are designed to make wage agreements generally binding should be abolished. If there is a case for generally binding wage contracts, these measures should be at least applied in a very careful manner and only under clear-cut circumstances, which have to be formulated as precisely as possible. Based on our analysis presented here, a substantial reform of the German labor law and the AVE system appears to be highly desirable.

Finally, our analysis may also apply to explicit minimum wage legislation, which exists in many countries, or to costly social obligations and standards imposed on employers. We think it would be a worthwhile future undertaking to further explore the interests employers may have in minimum wage legislation and in social obligations and standards that are imposed on entire industries or even economies, as it appears to be the case with the European Union's Social Charta. 


\section{References}

Akerlof, G.A.; Rose, A.K.; Yellen, J.L. \& Hessenius, H. [1991], "East Germany in From the Cold: The Economic Aftermath of Currency Union," Brookings Papers on Economic Activity, No. 1: 1-87.

Bughin, J. [1999], "The Strategic Choice of Union-Oligopoly Bargaining Agenda," International Journal of Industrial Organization, 17: 1029-1040.

Bundesministerium für Arbeit und Sozialordnung [1999], "Tarifvertragliche Arbeitsbedingungen im Jahre 1998," Geschäftszeichen IIIa3-31205-2, Bonn.

BunN, R.F. [1984], "Employers Association in the Federal Republic of Germany," pp. 169-201 in: J.P. Windmuller and A. Gladstone (eds.), Employers Associations and Industrial Relations: A Comparative Study, New York, Toronto and Oxford: Oxford University Press, Clarendon Press.

Calmfors, L. \& Driffill, J. [1988], "Bargaining Structure, Corporatism and Macroeconomic Policy," Economic Policy, 6: 13-47.

Deregulierungskommission [1991], Marktöffnung und Wettbewerb, Pöschel: Stuttgart.

Dornbusch, R. [1991], "Comments and Discussion on 'East Germany in From the Cold: The Economic Aftermath of Currency Union' by G.A. Akerlof et al.," Brookings Papers on Economic Activity, 1(1991): 88-105.

Dornbusch, R. [1992], "Economic Transition in Eastern Germany," Brookings Papers on Economic Activity, 1(1992): 235-272.

Franz, W. [1991], "German Labour Markets After Unification," Unpublished Paper, University of Konstanz (October). 
Freeman, R. [1988], "Labour Markets," Economic Policy, 6: 63-78.

Institut DeR Deutschen WiRTschaft [1997], Zahlen zur wirtschaftlichen Entwicklung der Bundesrepublik Deutschland, Deutscher Institutsverlag: Köln.

Jackman, R.; Pissarides, C. \& Savouri, S. [1990], "Labour Market Policies and Unemployment in the OECD," Economic Policy, 11: 449-483.

Keller, B. [1997], Einführung in die Arbeitspolitik, 5th edition, Oldenbourg: München.

Krattenmaker, T.G. \& Salop, S.C. [1986], "Anticompetitive Exclusion: Raising Rivals' Costs to Achieve Power Over Price," Yale Law Journal, 96: 209-293.

KREIMER-DE FrIES [1995], "Die Allgemeinverbindlichkeitserklärung von Tarifverträgen," pp. 203-229 in: R. Bispick (ed.), Tarifpolitik der Zukunft, VSA-Verlag: Hamburg.

Layard, R.; Nickell, S. \& Jackman, R. [1991], Unemployment, Macroeconomic Performance and the Labour Market, Oxford Univerity Press: Oxford.

Lindena, B. \& Höhmann, H. [1988a], "Viel Diskussion mit wenig Sachverstand," Der Arbeitgeber, 40: 465-467.

Lindena, B. \& Höhmann, H. [1988b], "Weniger allgemein als gemeinhin angenommen," Der Arbeitgeber, 40: 564-566.

Lindena, B. \& Höhmann, H. [1989], "Allgemeinverbindlichkeit von Tarifverträgen," Der Arbeitgeber, Special Issue (March), 3-9.

Maloney, M.T.; McCormick, R.E. \& Tollison, R.D. [1979], "Achieving Cartel Profits Through Unionization," Southern Economic Journal, 42: 628-634.

McDonald, I.M. \& Solow, R.M. [1981], "Wage Bargaining and Employment," American Economic Review, 71: 896-908. 
MEyer, D. [1992], "Zur Bedeutung von Allgemeinverbindlichkeitserklärungen," Jahrbuch für Sozialwissenschaft, 43: 364-374.

Monopolkommission [1994], Zehntes Hauptgutachten der Monopolkommission 1992 1993, Deutscher Bundestag, 12. Wahlperiode, Drucksache 12/8323, Deutscher Bundestag: Bonn.

NiCKELl, S. [1997], "Unemployment and Labor Market Rigidities: Europe versus North America," Journal of Economic Perspectives, 11: 55-74.

Nickell, S. \& Andrews, M. [1983], "Unions, Real Wages and Employment in Britain 1951-79," Oxford Economic Papers, Supplement, 35: 183-206.

OECD [1994], Employment Outlook, OECD: Paris.

Oswald, A.J. [1985], "The Economic Theory of Trade Unions: An Introductory Survey," Scandinavian Journal of Economics, 87: 160-193.

Petrakis, E. \& Vlassis, M. [1997], "Endogenous Wage-Bargaining Institutions in Oligopolistic Industries," Working Paper, Universidad Carlos III de Madrid, Madrid.

SACHVERSTäNDIGENRAT [1995], Jahresgutachten 1995/96 des Sachverständigenrates zur Begutachtung der Gesamtwirtschaftlichen Entwicklung, Bundestagsdrucksache 13/3016, Deutscher Bundestag: Bonn.

Salop, S.C. \& Scheffman, D.T. [1983], "Raising Rivals' Costs," American Economic Review, Papers and Proceedings, 73: 267-271.

Salop, S.C. \& Scheffman, D.T. [1987], "Cost-Raising Strategies," Journal of Industrial Economics, 36: 19-34.

Scheremet, W. [1992], "Der Arbeitsmarkt in Deutschland," Wochenbericht 56/92, Deutsches Institut für Wirtschaftsforschung, January 30. 
Scheremet, W. \& Schupp, J. [1992], "Pendler und Migranten: Zur Arbeitskräftemobilität in Ostdeutschland," Wochenbericht 3/92, Deutsches Institut für Wirtschaftsforschung, January 17.

Selten, R. [1965], "Spieltheoretische Behandlung eines Oligopolmodells mit Nachfrageträgheit," Zeitschrift für die gesamte Staatswissenschaft, 121: 301-324.

Sinn, G. \& Sinn, H.-W. [1992], Jumpstart: The Economic Unification of Germany, MIT Press: Cambridge, MA.

Williamson, O.E. [1968], "Wage Rates as a Barrier to Entry: The Pennington Case in Perspective," Quarterly Journal of Economics, 82: 85-116. 


\section{Bücher des Forschungsschwerpunkts Marktprozeß und Unternehmensentwicklung}

\section{Books of the Research Area Market Processes and Corporate Development}

(nur im Buchhandel erhältlich/available through bookstores)

Horst Albach, Ulrike Görtzen, Rita Zobel (Hg.)

Information Processing as a Competitive

Advantage of Japanese Firms

1999, edition sigma

Dieter Köster

Wettbewerb in Netzproduktmärkten

1999, Deutscher Universitäts-Verlag/Gabler Verlag

Christian Wey

Marktorganisation durch Standardisierung: Ein

Beitrag zur Neuen Institutionenökonomik des

Marktes

1999, edition sigma

Horst Albach, Meinolf Dierkes, Ariane Berthoin

Antal, Kristina Vaillant (Hg.)

Organisationslernen - institutionelle und

kulturelle Dimensionen

1998, edition sigma

Lars Bergman, Chris Doyle, Jordi Gual, Lars Hultkrantz, Damien Neven, Lars-Hendrik Röller, Leonard Waverman

Europe's Network Industries: Conflicting

Priorities - Telecommunications

Monitoring European Deregulation 1

1998, Centre for Economic Policy Research

Manfred Fleischer

The Inefficiency Trap

Strategy Failure in the

German Machine Tool Industry

1997, edition sigma

Christian Göseke

Information Gathering and Dissemination

The Contribution of JETRO to

Japanese Competitiveness

1997, Deutscher Universitäts-Verlag

Andreas Schmidt

Flugzeughersteller zwischen globalem

Wettbewerb und internationaler Kooperation

Der Einfluß von Organisationsstrukturen auf

die Wettbewerbsfähigkeit von

Hochtechnologie-Unternehmen

1997, edition sigma

Horst Albach, Jim Y. Jin, Christoph Schenk (eds.)

Collusion through Information Sharing?

New Trends in Competition Policy

1996, edition sigma
Stefan O. Georg

Die Leistungsfähigkeit japanischer Banken

Eine Strukturanalyse des Bankensystems in Japan

1996, edition sigma

Stephanie Rosenkranz

Cooperation for Product Innovation

1996, edition sigma

Horst Albach, Stephanie Rosenkranz (eds.)

Intellectual Property Rights and Global

Competition - Towards a New Synthesis

1995, edition sigma.

David B. Audretsch

Innovation and Industry Evolution

1995, The MIT Press.

Julie Ann Elston

US Tax Reform and Investment: Reality and Rhetoric in the 1980s

1995, Avebury

Horst Albach

The Transformation of Firms and Markets:

A Network Approach to Economic

Transformation Processes in East Germany

Acta Universitatis Upsaliensis, Studia Oeconomiae

Negotiorum, Vol. 34

1994, Almqvist \& Wiksell International

(Stockholm).

Horst Albach

"Culture and Technical Innovation: A Cross-

Cultural Analysis and Policy

Recommendations"

Akademie der Wissenschaften zu Berlin (Hg.)

Forschungsbericht 9, S. 1-597

1994, Walter de Gruyter.

Horst Albach

Zerissene Netze. Eine Netzwerkanalyse des ostdeutschen Transformationsprozesses

1993, edition sigma.

Zoltan J. Acs/David B. Audretsch (eds)

Small Firms and Entrepreneurship: An East-

West Perspective

1993, Cambridge University Press.

Anette Boom

Nationale Regulierungen bei internationalen Pharma-Unternehmen: Eine theoretische

Analyse der Marktwirkungen

1993, Nomos Verlagsgesellschaft. 
Horst Albach

Dietmar Harhoff

Karel Cool Lars-Hendrik Röller Benoit Leleux

Horst Albach

Shiho Futagami Tomoki Waragai Thomas Westphal

Dietmar Harhoff Timm Körting

Johan Lagerlöf

Justus Haucap Christian Wey Jens Barmbold

Manfred Fleischer

Dieter Köster

Andreas Blume

Andreas Blume Uri Gneezy

Andreas Blume Douglas V. DeJong George R. Neumann Nathan E. Savin

Hans Mewis

Lars-Hendrik Röller Mihkel M. Tombak Ralph Siebert

Christine Zulehner

Catherine Matraves
Unternehmensgründungen in Deutschland

FS IV $98-1$

Potentiale und Lücken

Vertical Organization, Technology Flows and R\&D Incentives - An Exploratory Analysis

Der Einfluß des tatsächlichen und des potentiellen Wettbewerbs auf die Rentabilität von Unternehmen der pharmazeutischen Industrie

Blühende Landschaften?

Ein Beitrag zur Transformationsforschung

FS IV $98-4$

Shukko in Japanese Companies and its Economic and Managerial Effects

Lending Relationships in Germany: Empricial Results from Survey Data

FS IV $98-6$

FS IV $98-7$ How the Economy Works?

Location Costs, Product Quality, and Implicit Franchise Contracts

FS IV $98-8$

FS IV $98-9$

Patenting and Industrial Performance: The Case of the Machine Tool Industry

Was sind Netzprodukte? - Eigenschaften, Definition und Systematisierung von Netzprodukten

FS IV $98-10$

Coordination and Learning with a Partial Language

FS IV $98-11$

An Experimental Investigation of Optimal Learning FS IV 98 - 12 in Coordination Games

Learning in Sender-Receiver Games

FS IV $98-13$

The Stability of Information Cascades: How Herd Behavior Breaks Down

FS IV $98-14$

The Incentives to Form Research Joint Ventures: Theory and Evidence

FS IV $98-15$

Econometric Analysis of Cattle Auctions

FS IV $98-16$

Market Structure, R\&D and Advertising in the Pharmaceutical Industry 


\section{DISCUSSION PAPERS 1999}

Suchan Chae Paul Heidhues

Christian Wey

Horst Albach

Jeremy Lever

Damien J. Neven Lars-Hendrik Röller Zhentang Zhang

Justus Haucap Uwe Pauly Christian Wey

Jianbo Zhang Zhentang Zhang

Justus Haucap Christian Wey

Yasar Barut Dan Kovenock Charles Noussair

$\operatorname{Jim} Y$. Jin

Jos Jansen

Johan Lagerlöf

Catherine Matraves

Pinelopi Koujianou Goldberg Frank Verboven

Olivier Cadot Lars-Hendrik Röller Andreas Stephan

Holger Derlien Tobias Faupel Christian Nieters
Bargaining Power of a Coalition in Parallel Bargaining: FS IV $99-1$ Advantage of Multiple Cable System Operators

Compatibility Investments in Duopoly with Demand FS IV 99 - 2 Side Spillovers under Different Degrees of Cooperation

Des paysages florissants? Une contribution FS IV $99-3$ à la recherche sur la transformation

The Development of British Competition Law: A Complete Overhaul and Harmonization

Union Power and Product Market Competition: Evidence from the Airline Industry

FS IV $99-4$

FS IV $99-5$

The Incentives of Employers' Associations to

FS IV $99-6$ Raise Rivals' Costs in the Presence of Collective Bargaining

Asymptotic Efficiency in Stackelberg Markets with Incomplete Information

Standortwahl als Franchisingproblem

FS IV 99 - 8

A Comparison of Multiple-Unit All-Pay and

FS IV $99-9$ Winner-Pay Auctions Under Incomplete Information

Collusion with Private and Aggregate Information

FS IV $99-10$

Strategic Information Revelation and Revenue Sharing FS IV 99 - 11 in an R\&D Race with Learning Labs

Incomplete Information in the Samaritan's Dilemma: FS IV 99 - 12 The Dilemma (Almost) Vanishes

Market Integration and Market Structure in the

FS IV $99-13$ European Soft Drinks Industry: Always Coca-Cola?

The Evolution of Price Discrimination in the European Car Market

FS IV $99-14$

A Political Economy Model of Infrastructure

FS IV $99-15$ Allocation: An Empirical Assessment

Industriestandort mit Vorbildfunktion?

FS IV $99-16$ 

Absender/From:

Versandstelle - WZB

Reichpietschufer 50

D-10785 Berlin

\section{BESTELLSCHEIN / ORDERFORM}

Bitte schicken Sie mir aus der Liste der Institutsveröffentlichungen folgende Papiere zu:
Bitte schicken Sie bei Ihren Bestellungen von WZB-Papers unbedingt eine 1-DM-Briefmarke pro paper und einen an Sie adressierten Aufkleber mit. Danke.

For each paper you order please send a "Coupon-

Réponse International" (international money order) plus a self-addressed adhesive label. Thank You.

Please send me the following papers from your Publication List: 
